\title{
Phosphorylation states of cell cycle and DNA repair proteins can be altered by the nsSNPs Sevtap Savas ${ }^{1,2,3}$ and Hilmi Ozcelik*1,2,3
}

\author{
Address: ${ }^{1}$ Fred A. Litwin Centre for Cancer Genetics, Samuel Lunenfeld Research Institute, Mount Sinai Hospital, Toronto, M5G 1X5, ON, Canada, \\ ${ }^{2}$ Department of Pathology and Laboratory Medicine, Mount Sinai Hospital, Toronto, M5G 1X5, ON, Canada and ${ }^{3}$ Department of Laboratory \\ Medicine and Pathobiology, University of Toronto, M5G 1L5, Toronto, ON, Canada \\ Email: Sevtap Savas - savas@mshri.on.ca; Hilmi Ozcelik* - ozcelik@mshri.on.ca \\ * Corresponding author
}

Published: 19 August 2005

BMC Cancer 2005, 5:107 doi:10.1 186/147|-2407-5-107
Received: 24 November 2004

Accepted: 19 August 2005

This article is available from: http://www.biomedcentral.com//47/-2407/5//07

(C) 2005 Savas and Ozcelik; licensee BioMed Central Ltd.

This is an Open Access article distributed under the terms of the Creative Commons Attribution License (http://creativecommons.org/licenses/by/2.0), which permits unrestricted use, distribution, and reproduction in any medium, provided the original work is properly cited.

\begin{abstract}
Background: Phosphorylation is a reversible post-translational modification that affects the intrinsic properties of proteins, such as structure and function. Non-synonymous single nucleotide polymorphisms (nsSNPs) result in the substitution of the encoded amino acids and thus are likely to alter the phosphorylation motifs in the proteins.
\end{abstract}

Methods: In this study, we used the web-based NetPhos tool to predict candidate nsSNPs that either introduce or remove putative phosphorylation sites in proteins that act in DNA repair and cell cycle pathways.

Results: Our results demonstrated that a total of 15 nsSNPs (16.9\%) were likely to alter the putative phosphorylation patterns of 14 proteins. Three of these SNPs (CDKNIA-S3 IR, OGGIS326C, and XRCC3-T24IM) have already found to be associated with altered cancer risk. We believe that this set of nsSNPs constitutes an excellent resource for further molecular and genetic analyses.

Conclusion: The novel systematic approach used in this study will accelerate the understanding of how naturally occurring human SNPs may alter protein function through the modification of phosphorylation mechanisms and contribute to disease susceptibility.

\section{Background}

Phosphorylation is a common, reversible post-translational modification that occurs at serine $(\mathrm{S})$, threonine $(\mathrm{T})$, and tyrosine $(\mathrm{Y})$ residues in proteins [1]. Overall, phosphorylation can alter the structure, function, interaction, stability, and the sub-cellular location of the proteins [2-4], and therefore play an indispensable role in regulation of the cellular processes such as signal transduction, gene expression, cytoskeletal regulation, apoptosis, homeostasis, cell cycle, and DNA damage recognition and repair [5-11]. The phosphorylation state of a protein is determined by the opposing actions of kinases and phosphatases [12]. Proteins may contain multiple phosphorylation sites, which may be targeted by different kinases/ phosphatases [2]. The activity of kinases and phosphatases at different times and/or upon different stimuli provides a means of powerful control over the protein phosphorylation state and thus the biological processes the protein is involved in.

In the post-genomic era, there is an expanding interest in identification of the single nucleotide polymorphisms 
(SNPs) that might affect the protein function and thus contribute to the disease susceptibility. The non-synonymous SNPs (nsSNPs) substitute encoded amino acids in proteins, and therefore are good candidates as diseasemodifiers. A variety of approaches have been developed and applied, based on criteria such as the evolutionary conservation status or structural parameters, to characterize and select the nsSNPs that are most likely to have functional consequences [13-19].

In this report, we predicted the potential effect of a set of nsSNPs $[20,21]$ in altering the phosphorylation status of DNA repair and cell cycle proteins using the NetPhos tool [22], which is an artificial neural network method that predicts the phosphorylation sites with a sensitivity of 69$96 \%$. DNA repair and cell cycle pathways interact during the cell growth and division to maintain the genomic stability of dividing cells. Abnormalities in the DNA repair and/or the cell cycle pathways can lead to abnormal cell growth/division or cellular death [23], and are implicated in many human diseases, including cancer [24-30]. Functional significance of many phosphorylated residues of several DNA repair and cell cycle proteins has already been evaluated. For example, phosphorylation of STAT $\alpha$ residue $S 727$ is required for its maximal transcriptional activation [31] and enhances its binding to the BRCA1 protein [32]. Similarly, phosphorylation of S383 and S387 are required for the FANCG function during mitosis [33]. Likewise, mutations of the phosphorylated residues Ser366 and Thr387 of p53 affect its transactivation function [34]. To our knowledge, although SNPs of DNA repair and cell cycle proteins have already been shown to contribute to cancer risk [35-37], the potential role of nsSNPs in alteration of phosphorylation patterns of proteins has not been evaluated before. Therefore, the novel approach described in this study will accelerate the formation of a bridge between variations in DNA repair/cell cycle function and predisposition to disease.

\section{Methods}

The nsSNPs extracted from public SNP databases were previously reported $[20,21]$, however, only the nsSNPs that were found in $\geq 2$ chromosomes in a sample panel of $\geq 46$ chromosomes were included into that manuscript. A total of 89 nsSNPs from 47 genes involved in DNA repair and cell cycle constituted the final data set. The NetPhos [22] algorithm was utilized to predict putative phosphorylation sites for both the wild type and the variant protein sequences. Only the predictions that remove or create a site at either the SNP location or at kinase recognition motifs are included into this manuscript. Please note that the BRCA1 and NFKB1 proteins were initially identified as cell cycle protein interacting proteins [21]. However, in this manuscript, we classified the BRCA1 as a DNA repair and the NFKB1 as a cell cycle protein. The mouse ortho- logues were retrieved from the LocusLink resource of NCBI [38] and aligned with the human proteins using the ClustalW program [39] to identify the corresponding mouse residue.

\section{Results and discussion}

We utilized the NetPhos algorithm to predict putative phosphorylation sites along the DNA repair and cell cycle proteins, and studied whether 89 naturally occurring nsSNPs (64 from 28 DNA repair and 25 from 19 cell cycle genes) might alter the phosphorylation patterns in these proteins. The sensitivity of NetPhos prediction has been reported to be $69-96 \%$ with a false-positive prediction rate of $0-26 \%$ for $\mathrm{Y}, 0-11 \%$ for $\mathrm{S}$, and $0-14 \%$ for $\mathrm{T}$ [22]. The results obtained using the NetPhos software are shown in Table I, and are summarized in Table II. Our results have shown that $16.9 \%(15 / 89)$ of the nsSNPs studied are likely to abolish or create 17 putative phosphorylation sites in $44.0 \%(14 / 32)$ of the proteins. As summarized in Table II, five nsSNPs (ERCC5-S311C, OGG1-S326C, XRCC3-T241M， CCND3-S259A, and CDKN1A-S31R) were predicted to abolish putative phosphorylation sites, whereas four nsSNPs were predicted to create putative phosphorylation sites in the proteins (ERCC2-H201Y, ERCC4-P379S, LIG4-P231S, and XRCC1-P309S). These nsSNPs resulted in the addition or removal of a S, T or Y residue at the predicted phosphorylation site.

The kinase recognition/interaction motif involves 7-12 amino acids around the phosphorylated residue [40], and the physicochemical characteristics of these amino acids determine the specificity of the protein kinases [41,42]. Thus, the amino acid substitutions within the kinase recognition motifs are likely to influence the substrate recognition and the subsequent phosphorylation by kinases. Accordingly, we have identified six nsSNPs (Table I, II) located within the phosphorylation motif of six proteins (within 4 amino acids on either side of the putative phosphorylated residue based on NetPhos outputs) that abolished eight putative phosphorylation sites (BRCA1-P871L at S868, BRCA1-S1040N at S1041, ERCC5-S311C at S310, IGHMBP2-T671A at S672, WRN-S1079L at S1083 and at S1084, CCNI-V207I at S208, and NFKB1-H712Q at T716). Interestingly, NetPhos predicts two overlapping phosphorylation motifs for the ERCC5-S311C nsSNP (S311 SLPSSSKMH and S310 ESLPSSSSKM), which are both completely abolished by the substitution of the serine residue (position 311) with a cysteine (Table I). Similarly, the WRN-S1079L nsSNP was also predicted to remove 2 putative overlapping phosphorylation motifs

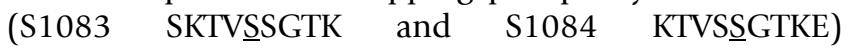
simultaneously. 
Table I: nsSNPs that abolish or create putative phosphorylated residues in DNA repair and cell cycle proteins. Only the NetPhos [22] predictions that remove or create a site at either the SNP location or at kinase recognition motifs are shown. The nsSNPs that create or abolish putative phosphorylation sites at the nsSNP position are shown in bold. Under the wild type and variant columns are the NetPhos outputs with the location of the amino acid, the phosphorylation motif (the putative phosphorylated residue is underlined), the score, and the residue being phosphorylated. I and 2 under the frequency column represents the nsSNP minor allele frequencies $<5 \%$ and $\geq 5 \%$, respectively [20-2I]. Please note that the BRCAI and NFKB I proteins were initially identified as cell cycle protein interacting proteins [2I]. However, in this manuscript, we classified the BRCAI as a DNA repair and the NFKBI as a cell cycle protein. $\S$ The putative phosphorylation sites that are also predicted in mouse proteins.

\begin{tabular}{|c|c|c|c|c|c|c|c|}
\hline Pathway & Gene & Accession \# & SNP ID & nsSNP & Freq. & Wild Type & Variant \\
\hline \multirow[t]{11}{*}{ DNA repair } & BRCAI & NM_007294.I & $\begin{array}{l}\text { SNP000007492 } \\
\text { rs799917 }\end{array}$ & P87IL & 2 & 868 SKRQSEFAPF $0.599 * S^{*}$ & - \\
\hline & BRCAI & NM_007294.I & rs4986852 & SI040N & I & $\S 104 \mid$ KEASSSSNIN 0.557 *S* & - \\
\hline & ERCC2 & NM_000400.I & $\begin{array}{l}\text { SNP000000054 } \\
\text { rsI799792 }\end{array}$ & H2OIY & I & - & 201 YSILYANVV $0.745 * Y *$ \\
\hline & ERCC4 & NM_005236.I & SNP000000067 & P379S & 1 and 2 & - & 379 LESNSKWWEA $0.507 * \mathbf{S} *$ \\
\hline & ERCC5 & NM_000123.I & $\begin{array}{l}\text { SNP001026027 } \\
\text { rs230749I }\end{array}$ & S3IIC & 1 & $\begin{array}{l}\text { a) } 3 \text { I I SLPSSSKMH } 0.990 * \mathbf{S} * \\
\text { b) } \$ 310 \text { ESLPSSSKM } 0.645 * S *\end{array}$ & - \\
\hline & IGHMBP2 & NM_002180.I & $\begin{array}{l}\text { SNP0000I } 2785 \\
\text { rs622082 }\end{array}$ & T67IA & 2 & $\S 672$ GPATSTRTG $0.634 * S *$ & - \\
\hline & LIG4 & NM_0023|2.2 & rs3093765 & P23IS & I & - & 23 I QLHDSSVGL $0.562 * S *$ \\
\hline & OGGI & NM_002542.4 & SNP000064679 & S326C & 2 & 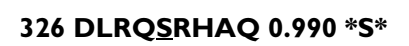 & -2 \\
\hline & WRN & NM_000553.2 & $\begin{array}{l}\text { SNP001026663 } \\
\quad \text { rs30874|4 }\end{array}$ & SI079L & 1 & $\begin{array}{l}\text { a) } \$ 1083 \text { SKTVSSGTK } 0.790 * S * \\
\text { b) } 1084 \text { KTVSSGTKE } 0.829 * S *\end{array}$ & - \\
\hline & $\mathrm{XRCCI}$ & NM_006297.I & $\begin{array}{l}\text { SNP000064196 } \\
\text { rs2549I }\end{array}$ & P309S & I & - & 309 EPRRSRAGP $0.996 *$ S* \\
\hline & $\mathrm{XRCC3}$ & NM_005432.2 & SNP000000060 & T24IM & 2 & $\S 24$ I SLGATLREL $0.849 * \mathrm{~T} *$ & - \\
\hline \multirow[t]{4}{*}{ Cell Cycle } & CCND3 & NM_00I760.2 & rs 1051130 & S259A & 2 & 259 LREASQTTSS $0.982 * \mathbf{S} *$ & - \\
\hline & $\mathrm{CCNI}$ & NM_006835.2 & rs4252903 & V207I & I & $\S 208$ LAMVSLEME $0.664 * S *$ & - \\
\hline & CDKNIA & NM_000389.2 & $\begin{array}{c}\text { SNP000003435 } \\
\text { rsI } 80 I 270 \\
\text { GAI87083I } \\
\text { GAlI50306I }\end{array}$ & S3IR & 2 & 3 I SEQLSRRDCD $0.924 * S *$ & - \\
\hline & NFKBI & NM_003998.2 & rs4648099 & $\mathrm{H} 7 \mathrm{I} 2 \mathrm{Q}$ & I & 716 HVDSITYDG $0.595 *{ }^{*} *$ & - \\
\hline
\end{tabular}

Table 2: Distribution of the nsSNPs predicted to alter the phosphorylation sites.

\begin{tabular}{|c|c|c|c|}
\hline nsSNP & DNA repair & Cell cycle & Total \\
\hline Abolished $\geq I$ putative phosphorylated residue $(\mathrm{S}, \mathrm{T}$ or $\mathrm{Y})$ at the nsSNP location & 3 & 2 & 5 \\
\hline Abolished $\geq$ I putative phosphorylated residue by changing the kinase recognition motif & 5 & 2 & 7 \\
\hline Created $\geq I$ putative phosphorylated residue $(S, T$ or $Y$ ) at the nsSNP location & 4 & 0 & 4 \\
\hline Created $\geq I$ putative phosphorylated residue by changing the kinase recognition motif & 0 & 0 & 0 \\
\hline
\end{tabular}

The Swiss-Prot [43], HPRD [44], PhosphoBase [45], and Phospho.ELM [46] databases and the existing literature did not reveal any experimentally verified phosphorylation at the predicted sites. Analysis of the mouse orthologues showed that the corresponding amino acids at the BRCA1-S1041, CCNI-S208, ERCC5-S310, IGHMBP2S672, WRN-S1083 and XRCC3-T241 residues were also predicted to be phosphorylated, suggesting that these motifs/sites might have been evolutionarily conserved between two species. On the other hand, the remaining phosphorylation sites, which are not detected in mouse proteins, may represent the newly evolved phosphorylation motifs in human. However, considering the false- positive rate of NetPhos as well as the possibility that the negative selection acting on the nsSNP sites can result in higher false-positive rates, we cannot totally rule out that all predictions in Table 2 are false. Yet these predictions are still of a great value and suggest possible phosphorylation sites that can be experimentally evaluated. In future, when sufficient molecular data regarding the phosphorylation status of orthologous proteins is available, more systematic analyses can be performed to maximize the accuracy of phosphorylation predictions.

We have also performed an extensive literature review to investigate the role of the reported nsSNPs (minor allele 
Table 3: Common nsSNPs with a possible role in cancer predisposition. Only the information derived from the studies on the protein function as well as the studies with a suggestion of disease-association have been included. I and 2 under the frequency column represents the nsSNP with minor allele frequencies $<5 \%$ and $\geq 5 \%$, respectively [20-2I].

\begin{tabular}{|c|c|c|c|c|c|c|}
\hline Pathway & Gene & nsSNP & Possible effect on phosphorylation & Frequency & Functional analysis & Cancer risk association \\
\hline \multirow[t]{5}{*}{ DNA repair } & BRCAI & P87IL & Abolishes at $\mathrm{S} 869$ & 2 & - & - \\
\hline & ERCC4 & P379S & Creates at S379 & 1 and 2 & - & - \\
\hline & IGHMBP2 & T67IA & Abolishes at $\mathrm{S} 672$ & 2 & - & - \\
\hline & OGGI & S326C & Abolishes at S326 & 2 & Yamane et al. [55] & $\begin{array}{l}\text { Sugimura et al. [52]; } \\
\text { Xing et al. [53]; } \\
\text { Elahi et al. [54] }\end{array}$ \\
\hline & $\mathrm{XRCC} 3$ & T24IM & Abolishes and T24I & 2 & Yoshihara et al. [5I] & $\begin{array}{l}\text { Winsey et al. [49]; } \\
\text { Kuschel et al. [47]; } \\
\text { Shen et al. [50]; } \\
\text { Figueiredo et al. [48] }\end{array}$ \\
\hline \multirow[t]{2}{*}{ Cell cycle } & CCND3 & S259A & Abolishes at S359 & 2 & - & - \\
\hline & CDKNIA & S3IR & Abolishes at S3I & 2 & Chedid et al. [59] & $\begin{array}{l}\text { Wu et al. [58]; } \\
\text { Roh et al. [56]; } \\
\text { Tsai et al. [57] }\end{array}$ \\
\hline
\end{tabular}

frequencies $\geq 5 \%$ ) in human cancer predisposition (Table III). Supporting our hypothesis, three SNPs (CDKN1AS31R, OGG1-S326C, and XRCC3-T241M) have already found to be associated with altered cancer risk. XRCC3T241M nsSNP was reported to be associated with increased breast cancer $[47,48]$ and melanoma risk [49], and was also found to be protective against bladder cancer in heavy smokers [50]. XRCC3 is a key DNA repair protein involved in base excision repair [29] and is involved in repairing the alterations caused by many DNA damaging agents. Recently, the XRCC3-M241 variant has been associated with increased risk of incidence of tetraploid cells, frequently observed in cancers, through affecting the function of the XRCC3- and Rad52-associated RPA protein [51]. Similarly, the OGG1-S326C SNP was found to be associated with increased lung [52], orolaryngeal and esophageal cancer risk $[53,54]$. OGG1 is a DNA repair protein that is protective against the mutations induced by the 8-hydroxyguanine. Yamane et al., [55] suggested that OGG1-C326, when compared to OGG1-S326, was associated with a lower repair capacity for 8-hydroxyguanine induced mutations in human cells. In the case of CDKN1A-S31R, the CDKN1A-S31 was suggested to be associated with increased endometrial cancer [56] whereas CDKN1A-R31 was associated with increased primary open-angle glaucoma [57] and esophageal cancer risk [58]. The CDKN1A-R31 form of the protein was not significantly different than the CDKN1A-S31 form in terms of its ability to suppress colony formation [59]. However, it is not clear whether this result would suggest that the CDKN1A-R31 would be functionally equivalent to the wild type allele in other diverse cellular mecha- nisms that the CDKN1A protein is involved in, such as apoptosis, cell migration, and senescence $[60,61]$.

In addition to the SNPs already implicated in cancer risk, we identified one relatively common nsSNP potentially altering the phosphorylation pattern of a major breast and ovarian cancer susceptibility gene, BRCA1. The BRCA1P871L SNP was not found to be associated with either breast [62] or ovarian cancer risk [63], however, further analyses is required to see whether this nsSNP or the other nsSNPs in Table III play a role in susceptibility to other cancer types.

How can we explain that commonly occurring nsSNPs (minor allele frequencies $\geq 5 \%$ ) are likely to affect the phosphorylation and thus the function of the proteins? If the phosphorylation site is necessary for the function of the protein and the protein is necessary for the fitness of the organism (indispensable/essential protein), then we would expect such nsSNPs (deleterious alleles) to be either removed from the population or be kept at low allele frequency by means of the purifying selection. Thus, in this case, one can conclude that the common nsSNPs presented in this report can be falsely predicted as removing/creating putative phosphorylation sites by NetPhos program. However, the allele frequencies of the deleterious alleles from proteins that are essential for fitness get higher than expected when the nsSNPs are a) created by hot-spot mutation mechanism(s), b) subject to balancing selection, too [64]. Alternatively, even though the nsSNPs (and the abolished/created phosphorylation sites) have important impact on the protein function, the protein and/or the altered protein function may not affect the fit- 
ness, which can also explain the lack of purifying selection against such nsSNPs and their relatively high minor allele frequencies. Besides, the biological consequences of altered protein function may only be exerted under certain environmental conditions.

\section{Conclusion}

Here we report a set of nsSNPs in DNA repair and cell cycle genes that are predicted to alter the phosphorylation motifs of the encoded proteins, with possible consequences on protein function, structure, interaction, and stability. If the nsSNPs with a $\geq 5 \%$ minor allele frequency listed in Table III do indeed alter the phosphorylation state of the corresponding proteins, they then represent important candidates for disease susceptibility studies, especially relating to cancer risk. We conclude with the suggestion that our approach and the resulting data indicate a novel mechanism of SNP action: alteration of the functional characteristics of the proteins through phosphorylation may significantly contribute to our understanding of the molecular basis of complex diseases, such as cancer. This study is unique in the sense that it systematically links the possible post-translational modification functional effects of SNPs to disease (cancer) predisposition.

\section{List of abbreviations}

SNP: single nucleotide polymorphism; nsSNP: non-synonymous SNP.

\section{Competing interests}

The author(s) declare that they have no competing interests.

\section{Authors' contributions}

SS participated in design of the study, collected and analyzed the data and prepared the draft of the manuscript. HO participated in the design and coordination of the study, and helped to draft the manuscript. Both authors read and approved the final manuscript.

\section{Acknowledgements}

Authors thank M. Farhan Ahmad, Mehjabeen Shariff, and David Y. Kim for technical assistance. We are indebted to Dr. Nikolaj Blom for his valuable communication about the false-positive rate of the NetPhos program. This work was supported by grants from the Susan Komen Breast Cancer Foundation, USA (BCTR0 100627), and the Canadian Breast Cancer Foundation (HO). S. Savas is supported, in part, by a "ClHR Strategic Training Program Grant - The Samuel Lunenfeld Research Institute Training Program: Applying Genomics to Human Health" fellowship.

\section{References}

I. Johnson LN, O'Reilly M: Control by phosphorylation. Curr Opin Struct Biol 1996, 6(6):762-769.

2. Cohen $P$ : The regulation of protein function by multisite phosphorylation - a $\mathbf{2 5}$ year update. Trends Biochem Sci 2000, 25(I 2):596-60I.
3. Pawson T: Specificity in signal transduction: from phosphotyrosine-SH2 domain interactions to complex cellular systems. Cell 2004, I I6(2): 191-203.

4. Zhang HG, Wang J, Yang X, Hsu HC, Mountz JD: Regulation of apoptosis proteins in cancer cells by ubiquitin. Oncogene 2004, 23(I I):2009-20I5.

5. Szumiel I: Monitoring and signaling of radiation-induced damage in mammalian cells. Radiat Res I998, I 50(5 Suppl):S92- I0I.

6. Graves JD, Krebs EG: Protein phosphorylation and signal transduction. Pharmacol Ther 1999, 82(2-3):III-12I.

7. Hunter T: Signaling - $\mathbf{2 0 0 0}$ and beyond. Cell 2000, I00(I): I13-127.

8. Henneke G, Koundrioukoff $S$, Hubscher U: Multiple roles for kinases in DNA replication. EMBO Rep 2003, 4(3):252-256.

9. McGowan $\mathrm{CH}$ : Regulation of the eukaryotic cell cycle. Prog Cell Cycle Res 2003, 5: I-4.

10. Vermeulen K, Van Bockstaele DR, Berneman ZN: The cell cycle: a review of regulation, deregulation and therapeutic targets in cancer. Cell Prolif 2003, 36(3): 13 I-149.

II. Westermann S, Weber K: Post-translational modifications regulate the microtubule function. Nat Rev Mol Cell Biol 2003, 4(12):938-947.

12. Lester LB, Scott JD: Anchoring and scaffold proteins for kinases and phosphatases. Recent Prog Horm Res 1997, 52:409-429.

13. Chasman D, Adams RM: Predicting the functional consequences of non-synonymous single nucleotide polymorphisms: structure-based assessment of amino acid variation. J Mol Biol 200I, 307:683-706.

14. $\mathrm{Ng}$ PC, Henikoff S: Predicting deleterious amino acid substitutions. Genome Res 200I, I I:863-874.

15. $\mathrm{Ng} \mathrm{PC}$, Henikoff S: Accounting for human polymorphisms predicted to affect protein function. Genome Res 2002, I 2:436-446.

16. Wang Z, Moult J: SNPs, protein structure, and disease. Hum Mutat 200I, 17:263-270.

17. Ramensky V, Bork P, Sunyaev S: Human non-synonymous SNPs: server and survey. Nucleic Acids Res 2002, 30:3894-3900.

18. Stitziel NO, Tseng YY, Pervouchine D, Goddeau D, Kasif S, Liang J: Structural location of disease-associated single-nucleotide polymorphisms. J Mol Biol 2003, 327(5): 102I-1030.

19. Clifford RJ, Edmonson MN, Nguyen C, Buetow KH: Large-scale analysis of non-synonymous coding region single nucleotide polymorphisms. Bioinformatics 2004, 20(7): |006-10|4.

20. Savas S, Kim DY, Ahmad MF, Shariff M, Ozcelik H: Identifying functional genetic variants in DNA repair pathways using protein conservation analysis. Cancer Epidemiol Biomarkers Prev 2004, 13(5):80I-807.

21. Savas S, Ahmad MF, Shariff M, Kim DY, Ozcelik H: Candidate nsSNPs that can affect the functions and the interactions of cell cycle proteins. Proteins 2005, 58(3):697-705.

22. Blom N, Gammeltoft S, Brunak S: Sequence- and structure-based prediction of eukaryotic protein phosphorylation sites. J Mol Biol 1999, 294(5): I351-1362.

23. Norbury CJ, Zhivotovsky B: DNA damage-induced apoptosis. Oncogene 2004, 23(16):2797-2808.

24. Latif $\mathrm{C}$, Harvey SH, O'Connell MJ: Ensuring the stability of the genome: DNA damage checkpoints. Scientific World Journal 2001, I:684-702.

25. Malumbres M, Barbacid M: To cycle or not to cycle: a critical decision in cancer. Nat Rev Cancer 200I, I(3):222-23I.

26. Duker NJ: Chromosome breakage syndromes and cancer. Am J Med Genet 2002, I I 5(3): I 25-129.

27. Thompson LH, Schild D: Recombinational DNA repair and human disease. Mutat Res 2002, 509(I-2):49-78.

28. Sarasin A: An overview of the mechanisms of mutagenesis and carcinogenesis. Mutat Res 2003, 544(2-3):99-106.

29. Thacker J, Zdzienicka MZ: The mammalian XRCC genes: their roles in DNA repair and genetic stability. DNA Repair (Amst) 2003, 2(6):655-672.

30. Motoyama N, Naka K: DNA damage tumor suppressor genes and genomic instability. Curr Opin Genet Dev 2004, I4(I): I I-I6.

3I. Zhu X, Wen Z, Xu LZ, Darnell JE Jr: Stat I serine phosphorylation occurs independently of tyrosine phosphorylation and requires an activated Jak2 kinase. Mol Cell Biol 1997:66I 8-6623.

32. Ouchi T, Lee SW, Ouchi M, Aaronson SA, Horvath CM: Collaboration of signal transducer and activator of transcription $I$ (STATI) and BRCAI in differential regulation of IFN- 
gamma target genes. Proc Natl Acad Sci U S A 2000, 97(10):5208-5213.

33. Mi J, Qiao F, Wilson JB, High AA, Schroeder MJ, Stukenberg PT, Moss A, Shabanowitz J, Hunt DF, Jones NJ, Kupfer GM: FANCG is phosphorylated at serines 383 and 387 during mitosis. Mol Cell Biol 2004, 24(19):8576-8585.

34. Ou YH, Chung PH, Sun TP, Shieh SY: p53 C-Terminal Phosphorylation by CHKI and CHK2 Participates in the Regulation of DNA-Damage-induced C-Terminal Acetylation. Mol Biol Cell 2005, I 6(4): 1684-1695

35. Goode EL, Ulrich CM, Potter JD: Polymorphisms in DNA repair genes and associations with cancer risk. Cancer Epidemiol Biomarkers Prev 2002, I I ( 12): I5 I3-1530.

36. Koike H, Suzuki K, Satoh T, Ohtake N, Takei T, Nakata S, Yamanaka $\mathrm{H}$ : Cyclin DI gene polymorphism and familial prostate cancer: the AA genotype of A870G polymorphism is associated with prostate cancer risk in men aged 70 years or older and metastatic stage. Anticancer Res 2003, 23(6D):4947-495I.

37. Chang BL, Zheng SL, Isaacs SD, Wiley KE, Turner A, Li G, Walsh PC, Meyers DA, Isaacs WB, Xu J: A polymorphism in the CDKNIB gene is associated with increased risk of hereditary prostate cancer. Cancer Res 2004, 64(6): 1997-1999.

38. Wheeler DL, Church DM, Edgar R, Federhen S, Helmberg W, Madden TL, Pontius JU, Schuler GD, Schriml LM, Sequeira E, Suzek TO, Tatusova TA, Wagner L: Database resources of the National Center for Biotechnology Information: update. Nucleic Acids Res 2004:D35-40.

39. Chenna R, Sugawara H, Koike T, Lopez R, Gibson TJ, Higgins DG Thompson JD: Multiple sequence alignment with the Clustal series of programs. Nucleic Acids Res 2003, 3 I ( I 3):3497-3500.

40. Songyang Z, Blechner S, Hoagland N, Hoekstra MF, Piwnica-Worms $H$, Cantley LC: Use of an oriented peptide library to determine the optimal substrates of protein kinases. Curr Biol 1994, 4(I I):973-982.

4I. Kreegipuu A, Blom N, Brunak S, Jarv J: Statistical analysis of protein kinase specificity determinants. FEBS Lett 1998, 430(I2):45-50.

42. Blom N, Sicheritz-Ponten T, Gupta R, Gammeltoft S, Brunak S: Prediction of post-translational glycosylation and phosphorylation of proteins from the amino acid sequence. Proteomics 2004, 4(6): 1633-1649.

43. O'Donovan C, Martin MJ, Gattiker A, Gasteiger E, Bairoch A, Apweiler R: High-quality protein knowledge resource: SWISS-PROT and TrEMBL. Brief Bioinform 2002, 3:275-284.

44. Peri $S$, Navarro JD, Amanchy R, Kristiansen TZ, Jonnalagadda CK, Surendranath V, Niranjan V, Muthusamy B, Gandhi T, Gronborg M, Ibarrola N, Deshpande N, Shanker K, Shivashankar HN, Rashmi BP, Ramya MA, Zhao Z, Chandrika KN, Padma N, Harsha HC, Yatish AJ, Kavitha MP, Menezes M, Choudhury DR, Suresh S, Ghosh N, Saravana R, Chandran S, Krishna S, Joy M, Anand SK, Madavan V, Joseph A, Wong GW, Schiemann WP, Constantinescu SN, Huang L, KhosraviFar R, Steen H, Tewari M, Ghaffari S, Blobe GC, Dang CV, Garcia JG, Pevsner J, Jensen ON, Roepstorff P, Deshpande KS, Chinnaiyan AM, Hamosh A, Chakravarti A, Pandey A: Development of human protein reference database as an initial platform for approaching systems biology in humans. Genome Res 2003, I3(10):2363-237|.

45. Kreegipuu A, Blom N, Brunak S: PhosphoBase, a database of phosphorylation sites: release 2.0. Nucleic Acids Res 1999, 27(I):237-239.

46. Diella F, Cameron S, Gemund C, Linding R, Via A, Kuster B, SicheritzPonten T, Blom N, Gibson TJ: Phospho.ELM: a database of experimentally verified phosphorylation sites in eukaryotic proteins. BMC Bioinformatics 2004, 5(I):79.

47. Kuschel B, Auranen A, McBride S, Novik KL, Antoniou A, Lipscombe JM, Day NE, Easton DF, Ponder BA, Pharoah PD, Dunning A: Variants in DNA double-strand break repair genes and breast cancer susceptibility. Hum Mol Genet 2002, I I (I 2): I 399- I 407.

48. Figueiredo JC, Knight JA, Briollais L, Andrulis IL, Ozcelik H: Polymorphisms XRCCI-R399Q and XRCC3-T24IM and the risk of breast cancer at the Ontario site of the Breast Cancer Family Registry. Cancer Epidemiol Biomarkers Prev 2004, I3(4):583-591.

49. Winsey SL, Haldar NA, Marsh HP, Bunce M, Marshall SE, Harris AL, Wojnarowska $\mathrm{F}$, Welsh $\mathrm{KI}$ : A variant within the DNA repair gene XRCC3 is associated with the development of melanoma skin cancer. Cancer Res 2000, 60(20):56I2-56I6.

50. Shen M, Hung RJ, Brennan P, Malaveille C, Donato F, Placidi D, Carta A, Hautefeuille A, Boffetta P, Porru S: Polymorphisms of the DNA repair genes XRCCI, XRCC3, XPD, interaction with environmental exposures, and bladder cancer risk in a case-control study in northern Italy. Cancer Epidemiol Biomarkers Prev 2003, I (I I Pt I): I 234-1240.

51. Yoshihara T, Ishida M, Kinomura A, Katsura M, Tsuruga T, Tashiro S, Asahara T, Miyagawa $\mathrm{K}: \mathrm{XRCC} 3$ deficiency results in a defect in recombination and increased endoreduplication in human cells. EMBO I 2004, 23(3):670-680.

52. Sugimura $H$, Kohno T, Wakai K, Nagura K, Genka K, Igarashi H, Morris BJ, Baba S, Ohno Y, Gao C, Li Z, Wang J, Takezaki T, Tajima K, Varga T, Sawaguchi T, Lum JK, Martinson J], Tsugane S, Iwamasa T, Shinmura K, Yokota J: hOGGI Ser326Cys polymorphism and lung cancer susceptibility. Cancer Epidemiol Biomarkers Prev 1999, 8(8):669-674.

53. Xing DY, Tan W, Song N, Lin DX: Ser326Cys polymorphism in hOGGI gene and risk of esophageal cancer in a Chinese population. Int J Cancer 200I, 95(3): I 40-I43.

54. Elahi A, Zheng Z, Park J, Eyring K, McCaffrey T, Lazarus P: The human OGG I DNA repair enzyme and its association with orolaryngeal cancer risk. Carcinogenesis 2002, 23(7): | 229- 1234.

55. Yamane A, Kohno T, Ito K, Sunaga N, Aoki K, Yoshimura K, Murakami H, Nojima Y, Yokota J: Differential ability of polymorphic OGGI proteins to suppress mutagenesis induced by 8 hydroxyguanine in human cell in vivo. Carcinogenesis 2004, 25(9): $1689-1694$

56. Roh JW, Kim JW, Park NH, Song YS, Park IA, Park SY, Kang SB, Lee HP: p53 and p2I genetic polymorphisms and susceptibility to endometrial cancer. Gynecol Oncol 2004, 93(2):499-505.

57. Tsai FJ, Lin HJ, Chen WC, Tsai CH, Tsai SW: A codon 3 Iser-arg polymorphism of the WAF-I/CIP-I/p2I/tumour suppressor gene in Chinese primary open-angle glaucoma. Acta Ophthalmol Scand 2004, 82(I):76-80.

58. Wu MT, Wu DC, Hsu HK, Kao EL, Yang CH, Lee JM: Association between $\mathrm{P} 2 \mathrm{I}$ codon $3 \mathrm{I}$ polymorphism and esophageal cancer risk in a Taiwanese population. Cancer Lett 2003, 20I(2): I75-180.

59. Chedid M, Michieli P, Lengel C, Huppi K, Givol D: A single nucleotide substitution at codon 3 I (Ser/Arg) defines a polymorphism in a highly conserved region of the p53-inducible gene WAFI/CIPI. Oncogene 1994, 9(10):302I-3024.

60. Roninson IB: Oncogenic functions of tumour suppressor p2 I(Wafl/Cip I/Sdil): association with cell senescence and tumour-promoting activities of stromal fibroblasts. Cancer Lett 2002, I79(I):I-14.

61. Coqueret $\mathrm{O}: \mathrm{New}$ roles for $\mathrm{p} 2 \mathrm{I}$ and $\mathbf{p 2 7}$ cell-cycle inhibitors: a function for each cell compartment? Trends Cell Biol 2003, 13(2):65-70.

62. Menzel HJ, Sarmanova J, Soucek P, Berberich R, Grunewald K, Haun $M$, Kraft HG: Association of NOOI polymorphism with spontaneous breast cancer in two independent populations. $\mathrm{Br} J$ Cancer 2004, 90(10): 1989-1994.

63. Wenham RM, Schildkraut JM, McLean K, Calingaert B, Bentley RC Marks J, Berchuck A: Polymorphisms in BRCAI and BRCA2 and risk of epithelial ovarian cancer. Clin Cancer Res 2003, 9(1 2):4396-4403.

64. Fay JC, $\mathrm{Wu} \mathrm{Cl}$ : Sequence divergence, functional constraint, and selection in protein evolution. Annu Rev Genomics Hum Genet 2003, 4:213-235.

\section{Pre-publication history}

The pre-publication history for this paper can be accessed here:

http://www.biomedcentral.com/1471-2407/5/107/pre pub 